\title{
Sustainable procurement portfolio management: a case study in a mining company
}

\author{
Tamires Magalhães de Mello ${ }^{\mathrm{a}}$, Daniel Eckhardt ${ }^{\mathrm{a}}$, Adriana Leiras ${ }^{\mathrm{a} *}$ \\ aPontifícia Universidade Católica do Rio de Janeiro, Rio de Janeiro, RJ, Brasil \\ *adrianaleiras@puc-rio.br
}

\begin{abstract}
Sustainable procurement is a solution to integrate environmental and social considerations in all steps of procurement process, in order to reduce impacts on human health, environment, and human rights. Despite the existence of important works in this area, more studies for determining how the principles related to sustainable development can be integrated to procurement strategies are needed. This study presents a case study in a mining company to evaluate the elements that should be considered for the implementation of sustainability concept in the contracting of services through the application of a sustainability portfolio model. Results show that the contracts of the internal movement's category of the studied company fit as Strategic Commodity, which means that the items in this category have a risk in the strategic supply, because they need investments made by the buyer in the relationship with the supplier.
\end{abstract}

Keywords

Sustainability. Procurement. Portfolio model. Sustainable procurement. Case study.

How to cite this article: Mello, T. M., Eckhardt, D., \& Leiras, A. (2017). Sustainable procurement portfolio management: a case study in a mining company. Production, 27, e20162136. http://dx.doi.org/10.1590/0103-6513.213616.

\section{Introduction}

The business activities are not limited to the economic sphere, they also have a significant effect on the environment and the society. Business activities, when done without an environmental concern, can increase air, water and soil pollution, leading to a climate change, among other environmental impacts. Similarly, the performance of a company affects and is affected by multiple groups of interest established by its shareholders, employees, suppliers, consumers, and also the community of the region where it is located, comprising a network of stakeholders.

The World Commission on Environment and Development (1987) states that sustainable development meets the needs of current generations without compromising the ability of future generations to meet their own needs. Ennis-Reynolds (2002) states that the policy for sustainable development rests on four main goals: (i) social progress that recognizes the needs of all; (ii) effective environmental protection; (iii) prudent use of natural resources; and (iv) maintenance of high and stable levels of economic growth and employment levels.

The current concept of sustainable development considers three key components: economic growth, environmental protection and social equality. These fundamentals coupled with the paradigm's shift on the companies, which were solely focused on profit, went through a sustainable development concept, originating the Triple Bottom Line of Sustainability: Economic Development, Social Development, and Environmental Development. Organizations before seen only as a catalyst of the economic process, have now undertook other roles, inter-relating with several agents, so they can continue working in their markets. Thus, companies have increasingly been led to work with the concept of sustainability.

To implement the concept of sustainable development in an organization is necessary the involvement and effort of several departments (Handfield et al., 1997; Wu \& Dunn, 1995). Tate et al. (2010) state that the procurement area can contribute to the implementation of the sustainability concept in the business environment 
mainly due to the position of the procurement process as the beginning of the flow of materials and services for a company (Carter et al., 1998; Porter \& Van der Linde, 1995). More specifically, each organization is as sustainable as its supply chain (Handfield et al., 2005; Krause et al., 2009). Therefore, companies that have the goal to be sustainable must first involve their suppliers and establish environmental and social performance standards for these suppliers (Sharma \& Henriques, 2005; Simpson et al., 2007).

Consequently, the application of a sustainability concept within a company inevitably involves the implementation of a sustainability concept within the procurement process.

Despite the existence of important studies in this area (Bowen et al., 2001; Meehan \& Bryde, 2011; Pagell et al., 2010), the subject of sustainable procurement is still in the early stages of understanding. More studies to establish how the principles connected to how the sustainable development may be combined to procurement strategies are needed (Meehan \& Bryde, 2011).

Under this context, this study's goal is to evaluate the elements that should be taken into account for the implementation of sustainability in the contracting of services. To meet this main goal, we carried out a case study in the procurement area of a mining company to assess the applicability of the sustainability portfolio model by Pagell et al. (2010) with an empirical perspective. Therefore, the main contribution of this paper is the implementation and evaluation of the model proposed by Pagell et al. (2010) in an actual company.

The procurement portfolio methods are systematics that enable the evaluation of the strategic importance of a purchase in many ways, as well as the difficulties in managing purchases. These portfolio methods also consist in the need for managers to develop different strategies for each type of supplier market and each category of purchased item in order for the company to achieve gains in the supply management (Weele, 2002). The portfolio model by Pagell et al. (2010) is based on the Kraljic (1983) model who was the first to introduce a procurement portfolio model. Pagell et al. (2010) is the first and most commonly used model that includes sustainability as a subject not originally handled by the Kraljic (1983).

This paper is divided into five sections: (i) introduction; (ii) theoretical foundation, which has the goal to identify the sustainability factors that can be used in the procurement process; (iii) the portfolio model with a sustainability dimension is presented; (iv) the research methodology; (v) the case study; and (vi) the final comments.

\section{Sustainable procurement}

The supply chain is comprised by the companies responsible for converting raw materials into finished products to their final destination, i.e., until the consumer takes possession of the goods and uses them. Procurement activities take place several times throughout this process, contributing to an improved composition of costs and reducing waste throughout the supply chain.

In an increasingly dynamic environment, the strategic importance of the procurement activities has been evident in organizations, regardless of the size and the nature of the business (Carter \& Narasimhan, 1996; Weele, 2010). The procurement area, therefore, plays a key role in achieving the company strategic goals, as it may affect the delivery time of products and services, in addition to the operating costs and product/service quality - key elements in operation strategy of any company (Gaither \& Frazier, 2001). For Carr \& Smeltzer (1999), the strategic procurement's function is to direct its activities to objectives and long-term goals which aim to give a competitive advantage to the organization.

Currently, there is a consensus among researchers that the concept of sustainability must be analyzed comprehensively because it is a complex issue with many approaches. A firm's corporate image, in terms of its economic, environmental and social behavior, heavily depends on its supply chain and the sustainability performance of each and every chain link, including both primary and second-tier suppliers (Xie, 2016). Overall, the definitions seek to integrate economic viability with ecological prudence and social justice, in the three dimensions known as Triple Bottom Line. Economic development refers to the generation of wealth; environmental protection concerns the impact on the natural and social systems; and the social inclusion addresses the problems related to the maldistribution of income, health and opportunities.

Social performance is addressed through the analysis of the impact of the organization on its stakeholders - employees, partners, suppliers, consumers/customers, community and society in general (Karna et al., 2003).

To Andrade et al. (2000), environmental sustainability is the examination and review of the operations through the company ecology perspective motivated by a change in the corporate culture's values, evolving from domination to partnership, from the ideology of economic growth to the ideology of environmental sustainability. Briefly, environmental sustainability means to increase the planet capacity by using the potential found in many ecosystems, while maintaining a minimum level of deterioration of these ecosystems. 
Industrialization contributed to the economic growth, accelerating changes in the structures, spreading the capital and the technology, and also turned out expanding market failures and policy distortions. So, industrialization also increased environmental damage and disregarded the social aspects. Economic sustainability thus covers all aspects of economic interactions that can exist between an organization and its stakeholders, including the results traditionally presented in financial statements (profitability indicators), but, above all, the indicators that will allow the evaluation on how the stakeholders are affected by the activities of the company.

One of the issues related to the sustainable development, which is highlighted nowadays, is the corporate sustainability because of its relationship to get a competitive advantage. Companies are looking to enter the Triple Bottom Line in the strategy and management of their business, which consists on seeking market continuity and the growth of the organization from its economic viability, as well as the harmonious coexistence with the environment and society (Porter \& Kramer, 2006). Thus, a new concept of business arises oriented to sustainability practices whose main characteristic is the effort to reduce their environmental and social impacts through the adaptation of its products, processes, and organizational structures. Companies must conduct their business through activities that respect the environment (Schaltegger et al., 2003).

According to Ruparathna \& Hewage (2015), promoting the sustainable development through procurement should overcome the number of flaws identified in traditional procurement processes. Sustainable procurement is a way to integrate environmental and social considerations in all steps of procurement and contracting process, in order to reduce impacts on human health, environment, and human rights.

BCSD Portugal (2008) mentions that sustainable procurement offers several benefits for society and organizations. For organizations: (i) Benefits in results (lower operating costs, reduced energy, water consumption etc.); (ii) Risk reduction (reduction of accident risks, decrease of direct and indirect costs); (iii) Strengthening the image (organization's commitment to a policy of sustainability and social responsibility, improve the working employee conditions). For companies: (i) Stronger economy (contributes to the market development for sustainable products/services, reduces energy and material costs which increase the funds available for other purposes); (ii) Healthier environment (reduction of waste, more efficiently use of raw materials); (iii) Increase in social welfare (promotes the development of local suppliers, support to suppliers who have a strong commitment to local communities and great social and environmental responsibility).

\section{Portfolio model with a sustainability dimension}

For Sancha et al. (2016), if companies aim to achieve a truly socially responsible supply chain (i.e., they need their suppliers to be sustainable), they need to collaborate with them. This need to develop different strategies stems from the inability to employ advanced relationships with all suppliers due to resource and external factors constraints.

The Kraljic model is considered an important reference of the development of the theory in the supply management's area. Although there are criticisms on this model, other approaches of procurement management models found in the literature (Hadeler \& Evans, 1994; Olsen \& Ellram, 1997; Bensaou, 1999) are still referenced on the Kraljic model.

Using criteria such as volume purchased, percentage of the total purchase cost, availability, and number of suppliers, the model proposed by Kraljic (1983) allows the decision-maker to sort all the products purchased by the company according to its impact on profitability (importance) and the supply risk (complexity of the supplier market). As shown in Figure 1, the method creates a categorization structure of the items purchased and the supplier market, divided into four categories: (i) Non-Critical ltems; (ii) Leverage Items; (iii) Strategic Items; and (iv) Critical items. For each of these categories, different procurement strategies are suggested.

One of the biggest criticisms on the model proposed by Kraljic is that by reducing the issues to two dimensions, the matrix representation does not capture relevant aspects of contemporary business transactions, such as business carried out through company networks (Dubois \& Pedersen, 2002); the interdependence between products (Terpend et al., 2011); and the concept of competitive and sustainable advantage in inter-company relationships (Pagell \& Wu, 2009).

In addition, to classify purchases in the portfolio model, the company needs to assign weights to the criteria and factors based on the perception of managers and on the organization's information (Olsen \& Ellram, 1997; Gelderman \& Van Weele, 2003).

Some authors (for example, Hadeler \& Evans, 1994; Olsen \& Ellram, 1997; Bensaou, 1999) have used basic ideas of Kraljic to develop similar models, although there are more similarities than differences when compared to the original Kraljic matrix. However, there are several applications of the Kraljic model with changes, such as development of suppliers (Handfield et al., 2000), purchases on the internet of maintenance, repair, 


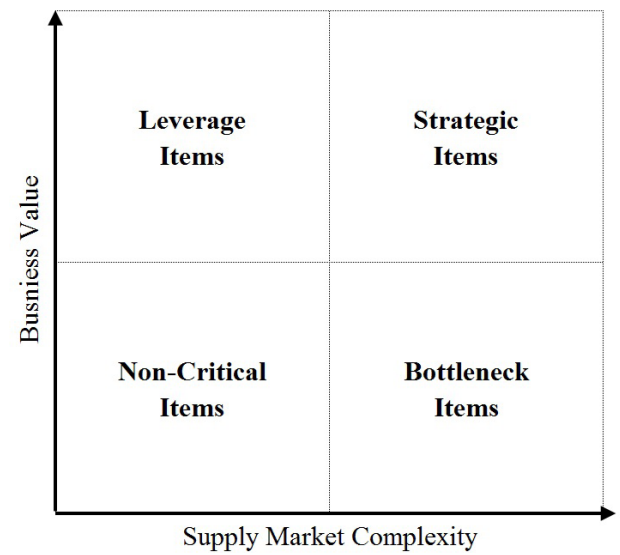

Figure 1. Simplified Kraljic model. Source: Adapted from Kraljic (1983).

operations (MRO) items (Croom, 2000), process specification (Nellore \& Soderquist, 2000), and development of inter-organizational competence (Gelderman \& Van Weele, 2002).

According to Pagell et al. (2010), there were many changes in the companies' supply management since Kraljic proposed its procurement portfolio model in 1983. Sustainability is a topic not originally handled by the model, but a concern that affects many business today. When social and environmental concerns are important drivers for procurement decisions, the categorization of suppliers, which originally emphasized the economic aspects, becomes inadequate (Amindoust et al., 2012).

The concern with business continuity and its relationship with the supply base is critical to the Sustainable Supply Chain Management - SCCM. The idea of continuity should be of great importance on the social and environmental actions of the supplier. It should extend throughout the supply chain, not just the first tier of suppliers. Table 1 shows five practices focused on supply base continuity.

Table 1 . Continuity practice of the supply base.

\begin{tabular}{ll}
\hline \multicolumn{1}{c}{ Continuity Practice } & \multicolumn{1}{c}{ Description } \\
\hline Decommoditization & $\begin{array}{l}\text { Treatment of a supplier and/or supply chain that provides a commodity (levered or noncritical } \\
\text { items: competition primarily in price) as a strategic item supplier. Buyers establish long-term } \\
\text { contracts and pay a price above the market for items that are usually bought in a perfectly } \\
\text { competitive market, aiming at the lowest price. }\end{array}$ \\
\hline Traditional supplier development & Train suppliers to be the best supplier for the purchasing company. \\
\hline Reduce the risk of suppliers & $\begin{array}{l}\text { Helping suppliers to reduce some or all of the risks associated with providing more sustainable } \\
\text { products and services. }\end{array}$ \\
\hline Nontraditional development of supplier & Train suppliers to be the best supplier in the sector. \\
\hline Transparency & All supply chain members have to provide a complete account of cash flow to the source.
\end{tabular}

Based on the continuity practices of the supply base found in the surveyed companies, Pagell et al. (2010) proposed modifications in the Kraljic procurement model. This update considers social and environmental aspects in the dimensions of the matrix, given the concept of the Triple Bottom Line. From the initial four categories of the Kraljic model (1983), the revision proposes six categories with the largest changes for leveraged items as set in Figure 2 and Table 2.

In the vertical axis of Figure 2, as in Table 2, is possible to see the change in the dimension "importance of purchase" of the original Kraljic matrix for the dimension "threat to the profits, the environment and the society", i.e., the Triple Bottom line and not only the financial aspects should be analyzed.

The characteristics of each segment in the Pagell et al. (2010) model are:

a. Strategic ltems: The change in this category is in its importance, which is not restricted to economic aspects, but may involve social and environmental elements;

b. Bottleneck 1tems: No changes. The bottleneck items involve low impact on any of the Triple Bottom Line elements, but high risks of supply; 
The Sustainable Purchasing Portfolio Matrix

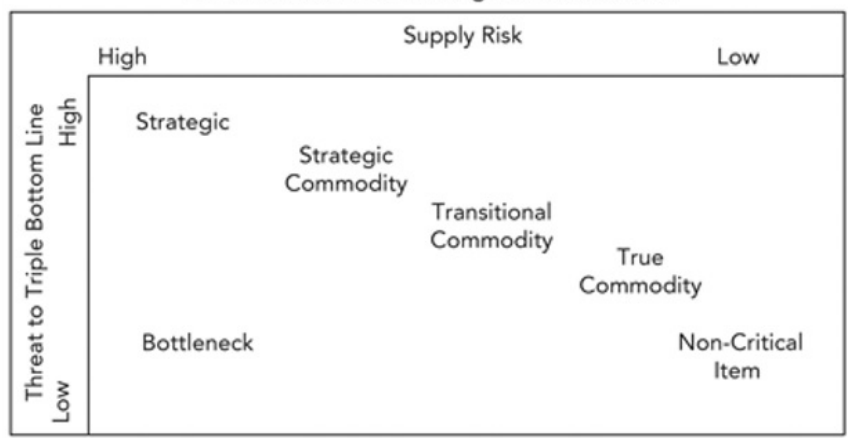

Figure 2. Sustainable Procurement Portfolio Matrix. Source: Pagell et al. (2010).

Table 2. Categories of the Revised Portfolios Matrix.

\begin{tabular}{lccc}
\hline Category Kraljic & New Category & Supply Risk & $\begin{array}{c}\text { Threat to the profits, } \\
\text { environment and society }\end{array}$ \\
\hline Strategic ltem & Strategic ltem & High & At least one high \\
\hline Bottleneck ltem & Bottleneck ltem & High & All low \\
\hline Noncritical item & Noncritical item & Low & All low \\
\cline { 2 - 4 } Leveraged ltem & True Commodity & Low & One high and the others low \\
& Transitory Commodity & $\begin{array}{c}\text { Currently high due to the } \\
\text { information asymmetry. Will } \\
\text { return to low. }\end{array}$ & One high and the others low \\
\cline { 2 - 4 } & Strategic Commodity & Buyer takes from low to high & At least one high
\end{tabular}

Source: Pagell et al. (2010).

c. True Commodity: Among the three new categories derived from the leveraged items, this is the most similar to the original. It has importance on just one element of the Triple Bottom Line and a risk of short supply, so it does not generate great difficulties when switching suppliers;

d. Transitional Commodity: Derived from the category of leveraged items, it involves the continuity practices of the supply base with the short term nature;

e. Strategic Commodity: Also derived from the category of leveraged items, involves the continuity practices of the supply base with long-term. Investments are carried out due to social and environmental elements - this initiative minimizes threats to the Triple Bottom Line and creates new opportunities for a lasting relationship, but increases the risk of investment loss if the supplier is replaced;

f. Non-critical ltems: Does not present changes regarding the Kraljic model. The goal in the management of this category is to get the lowest cost of supply.

According to Pagell et al. (2010), with the adoption of sustainable principles in the selection process, a smaller number of suppliers is used. Closer relationships - with longer contracts, as highlighted above - to items previously treated as mere commodities being adopted, which results in the reduction

The key goal of the Kraljic model was also analyzed by Krause et al. (2009) in the case in which managers seek to build a Sustainable Supply Chain. To analyze the incorporation of sustainable aspects, the authors drew on the theory of competitive priorities. A competitive priority is a strategy defined by an organization, in parallel to its overall strategy to act on a specific market (Hayes \& Wheelwright, 1984). They suggest that sustainable development could be a new competitive priority, considered in conjunction with other traditional competitive priorities: quality, cost, reliability, timeliness, flexibility and innovation. The proposal is to include sustainability as a key criteria of performance in all four quadrants of the Kraljic (1983) model as shown in Figure 3.

For strategic items, it is important to focus on aspects connected to innovation, ensuring that their suppliers consider sustainable aspects in the development of their products. Furthermore, in this case, the collaboration and sharing of know-how are important to ensure the minimization of social and environmental impacts of new products. For leverage items, the emphasis on reducing the consumption of raw materials and the use of recycled materials, for example, gains importance. For the bottleneck items, the adoption of sustainable practices is more difficult because the purchase organization is in a situation of dependence. In these cases, the purchasing 


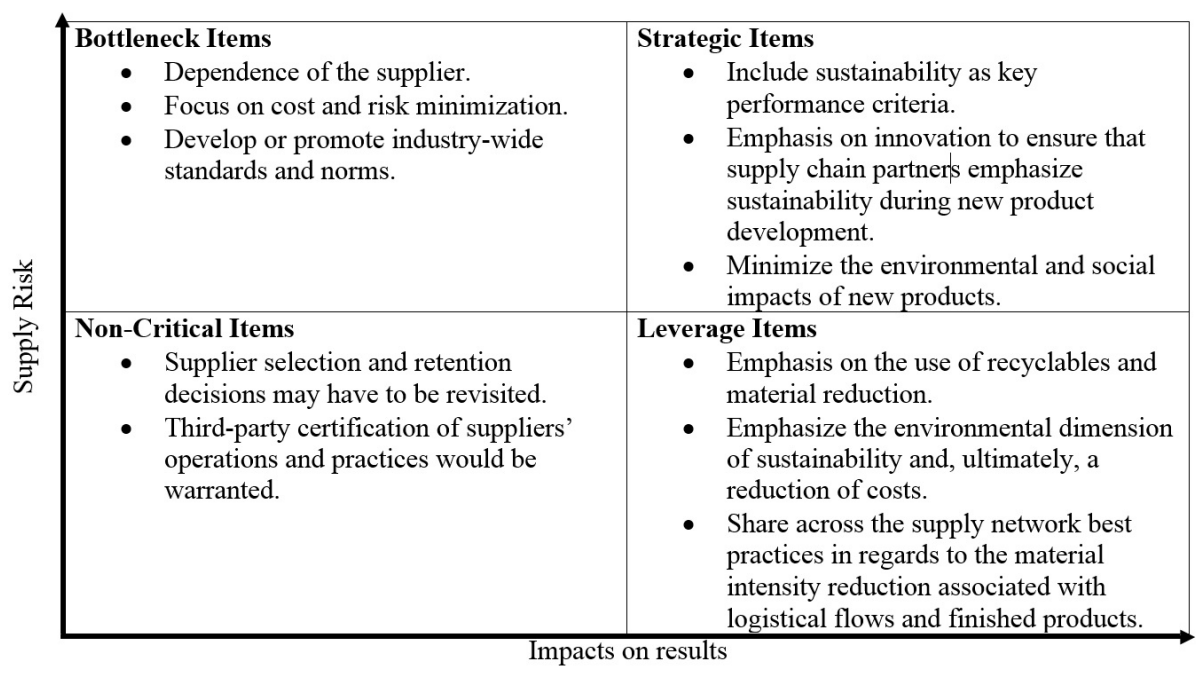

Figure 3. Matrix Including Sustainability in the Categories of the Kraljic Model. Source: Krause et al. (2009).

organization can encourage the adoption of standardization and certification in supplier organizations. Finally, for noncritical items, the proposal is to adopt simple qualifying criteria for suppliers, such as requiring some certification.

The final comments of Krause et al. (2009) from the construction of the model shown in Figure 3 indicate that organizations will require a level of sustainability of its suppliers according to the type of component/item required at time of procurement. At the same time, some companies will adopt sustainability in a unilateral way, as part of their business strategy, while others will be coerced to integrate sustainability by its customers, suppliers, or the law. Some may choose to focus their efforts only on environmental and economic dimensions and others may also enter social and cultural issues such as performance evaluation factors.

The focus of Krause's et al. (2009) paper is seeking to understand if including sustainability in the procurement process of an organization can generate some kind of impact on the development of strategic purchases, in the relationship with and in the performance of suppliers. If the impact of this integration is positive, the procurement management area would fail to meet its operational role and would represent a strategic character resulting from the construction of a new area called sustainable supply management. From this assumption, it is understood that the procurement actions that consider aspects of sustainability are crucial to the creation and consolidation of sustainable supply chains.

\section{Research methodology}

This paper was structured in accordance to Yin's (2005) approach to develop the case study. The case study's goal is to create evidences regarding the relationship, including its elements and items, between sustainability and procurement; in addition, it also seeks to understand whether the items that characterize a sustainable purchase can be applied to other types of purchases.

The case study was carried out primarily to confirm the category of internal movement as belonging to the leverage quadrant of the Kraljic Matrix (Kraljic, 1983) and, secondarily, to implement the Pagell et al. (2010) model, using the Narasimhan (1983) method to position the portfolio of contracts in both studies. This method was used because both models do not clarify which scale should be used to position the items selected for the study and how to classify the procurements in the portfolio model; the company needs to assign weights to the criteria and perception-based factors from the managers and organizational information (Gelderman \& Van Weele, 2003).

The Narasimhan (1983) method has the following steps: (i) all factors selected are placed in a matrix and an evaluation is carried out comparing the degree of importance of one factor against the other pursuant to predefined weights; (ii) the geometric mean of each line is carried out; (iii) the weight of each factor is calculated by dividing the geometric mean of each line by the sum of the geometric means of all line factors; (iv) the weight is then multiplied by a Risk Factor, previously established (based on consensus) by the focus 
group; (v) the sum of the results of the step (iv) indicates the score of the axis in question. After identifying in which quadrant the category of internal movement must be positioned, the same method was applied for the Pagell et al. (2010) model to evaluate the sustainability factor in the procurement process. Figure 4 shows an example of the methods applied in three premises (Premise 1, Premise 2, Premise 3).

\begin{tabular}{|c|c|c|c|c|c|c|c|c|}
\hline Weights & \multicolumn{3}{|l|}{ Definition } & \multicolumn{2}{|c|}{ Risk Rate } & \multicolumn{3}{|c|}{ Definition } \\
\hline 1 & \multicolumn{3}{|c|}{ Same relevance } & \multicolumn{2}{|c|}{1} & \multicolumn{3}{|c|}{ Very low relevance } \\
\hline 3 & \multicolumn{3}{|c|}{ A little more relevant } & \multicolumn{2}{|c|}{3} & \multicolumn{3}{|c|}{ Low relevance } \\
\hline 5 & \multicolumn{3}{|c|}{ Considerably more relevant } & \multicolumn{2}{|c|}{5} & \multicolumn{3}{|c|}{ Moderate relevance } \\
\hline 7 & \multicolumn{3}{|c|}{ A lot more relevant } & \multicolumn{2}{|c|}{7} & \multicolumn{3}{|c|}{ High relevance } \\
\hline 9 & \multicolumn{3}{|c|}{ Extremely relevant } & & & \multicolumn{3}{|c|}{ Very high relevance } \\
\hline \multicolumn{4}{|c|}{$\nabla$} & & \multicolumn{4}{|c|}{$\nabla$} \\
\hline & Premise 1 & Premise 2 & Premise 3 & $\mathbf{Z}$ & & $\mathbf{W}$ & Risk Rate & Score \\
\hline Premise 1 & 1.000 & 3.000 & 7.000 & 2.759 & & $68 \%$ & 1.000 & 0.680 \\
\hline Premise 2 & 0.333 & 1.000 & 0.200 & 0.405 & & $10 \%$ & 5.000 & 0.500 \\
\hline Premise 3 & 0.143 & 5.000 & 1.000 & 0.894 & & $22 \%$ & 5.000 & 1.101 \\
\hline & & & Sum: & 4.058 & & $00 \%$ & & 2.281 \\
\hline
\end{tabular}

Figure 4. Example of calculation of a Kraljic position based on the Narasimhan (1983) method.

The data collected for the case study resulted from a research on the internal documents of the company studied, such as contracts reports, consumer information of the contracts and, especially, a structured questionnaire to record the data required for the classification of the items in the selected sample. Two steps were structured to prepare the questionnaire: initially, the parameters needed to assess and apply the selected models (Kraljic, 1983; Pagell et al., 2010) were identified and it was established an appreciation form regarding the scale and weigh of the results using the Narasimhan (1983) scale. The weighing scale may be revised after being presented to the same focus group. The questions connected to the questionnaire for horizontal axis and vertical axis of the Kraljic (1983) model and the Pagell et al. (2010) model are presented in the next section.

After, the sample of items evaluated was established, then the field research itself was carried out. It is noteworthy that the items together representing $80 \%$ of the estimated annual expenditure of the category were selected from existing and valid contracts belonging to this category. This percentage was decided based on an $\mathrm{ABC}$ analysis. The category of internal movement has 48 current contracts in its portfolio. Of these, 12 comprise $80 \%$ of the annual expenditure of the category. These 12 contracts formed the sample to be analyzed together with the analysts responsible for them.

This questionnaire was applied to a focus group consisting of all the professionals working in the category of internal movement. Thus, it mitigates the risk of individual perceptions and has the point of view of several experts who work in this category. For the questionnaire, a focus group of eleven (11) professionals working in the category of internal movement (from 1,5 to 8 years of experience) was consulted: 1 Manager, 1 Supervisor, 1 Assistant, 4 Junior Analysts, 1 Senior Analyst and 3 Senior Analysts.

To analyze the data and apply the models (Kraljic, 1983; Pagell et al., 2010), two different study days (on site) were necessary with the focus group. On day one, the weights and the parameters to be evaluated within each item of each model were established (the key elements of the literature overview were described to the focus group, which agreed with the topics and added other elements to be analyzed). On day two, the questionnaire was applied to assess the items established on day one. The answer to the questions along with the reasoning was given by each individual separately. For the application of the comparisons between the items and the degree of risk and for the consolidation of the reasoning for each item, the discussion involved everyone in the focus group. For the items of the questionnaire, the issues discussed were based on each contract. That is, each person answered a questionnaire for each contract of the sample. The total time used for the case study adding up the two days was of 10 hours.

On day one, the focus group agreed to use the weighting factors proposed by Narasimhan (1983). Given that this method can be considered subjective by each person, the item was evaluated in a subjective basis. After applying the questionnaire day two, if there was any disagreement on the individual findings of the evaluation, the matter was brought for discussion between all involved. After reaching a consensus on the filling of the scores set, the reasoning was read to get to a single reasoning to represent the analyzed criteria. 
Furthermore, it was decided and agreed with the focus group that if more than $80 \%$ of the sample contracts studied fell into a specific quadrant, this would be taken into account for the appropriate subdivision of the strategic process of the contracts in the category of internal movement. Otherwise, more than one subdivision would be analyzed.

\section{Case study}

Mining is one of the base industries of Brazil's economy, decisively contributing to the well-being and the improvement of the life quality for present and future generations. The mineral products are essential for several industries such as civil construction, machinery and equipment, automotive, aerospace, naval, railway equipment, among others.

Due to the nature of this activity the risk to the Triple Bottom Line is very big. According to Hilson \& Murck (2000), the great challenge for mining companies to achieve the sustainable development required by multiple stakeholders involved in this activity is to go beyond what is dryly set in the law, that is, seeking to establish goals that require them to raise their social development standards of the community involved and fulfill an environmental management model in anticipation of the mining activity's problems.

This study considers a company of the Brazilian mining industry, which is considered the world's largest producer of iron ore and pellets and the second largest of nickel. The company was selected since sustainability is one of its strategic pillars. It has a focus on health and safety, optimization of resources, construction of a positive legacy for communities close to its operations and adoption of best practices in social and environmental management. In 2013, resources invested in the socio-environmental area reached 1.3 billion US dollars, with almost $79 \%$ for environmental initiatives and $21 \%$ for social actions. Still in 2013 , the company sought to encourage its suppliers in the areas of sustainability and climate change. One of the tools offered was the ability for suppliers to carry out inventories of gas emissions. Another initiative is a program to encourage the development of suppliers where the company has released 415 million US dollars in financing and credits for this purpose. In addition, the company participates in global discussions and initiatives that promote sustainability. Since 2011, the company is a member of the select group of companies that are part of the United Nations Global Lead Pact and is also part of the International Council on Mining and Metals (ICMM), aiming at the continuous improvement of sustainability management.

In this company, the procurement department is divided into service procurement and material procurement. This study covers only the service procurement department that is divided into two general managers, and each of these into smaller managements. Each of these category groups has an area's manager, supervisors and a group of buyers specialized in the categories in which they work with. In this study, the category of internal movement is analyzed.

The internal movement procurement category includes procuring services for the activities of moving and transporting products, materials, waste, among others, as well as recovery and maintenance activities of roads and wetting batteries, and access roads within the facilities of mine, port, power plant or rail and can be divided into four categories: (i) Service of Internal Cargo Movement; (ii) Service of Internal Movement with Off-Highway Equipment; (iii) Leasing Equipment for Internal Movement; and (iv) Leasing Off-Highway Equipment. The main difference between the procurement of service and of leasing is the manpower that will operate the equipment belonging to the scope. In the service contract, the workmanship is the supplier's responsibility, and in the leasing contract is the contracting company's responsibility.

The key variables used when choosing suppliers are: operational safety, quality, price, number of complaints from user areas in relation to the services previously provided by the suppliers, and waste management policy. One of the biggest problems faced by suppliers who meet this category is the lack of skilled workforce. Due to this fact, higher salaries are needed to retain qualified personnel and additional personnel costs with training, which may impact the contracts costs. Regarding the contract costs of the internal movement, most of the costs are related to the equipment and to the manpower required in the contract.

The internal movement category was positioned by the studied company at the leverage quadrant the Kraljic matrix, by a method performed by an external consultant hired to assist in the preparation of the strategic planning of the category in 2013.

\section{Application of Kraljic (1983) Model}

Currently, the internal movement category of this mining company is positioned in the leverage quadrant of the Kraljic matrix. However, seeing that this positioning was carried out by a consultant hired by the company and that the method used was adapted to the reality of the company, not in accordance with what was found 
in the literature, it was then made a new assessment of the category for it to be positioned in accordance with the Kraljic model explained in the literature.

To assess the supplier market's complexity axis, five premises were selected and the financial dependence was added to this list, considered important by the interviewed professionals.

For each of the items shown in Table 3, it was applied the method of Narasimhan (1983) to evaluate the horizontal axis of the Kraljic matrix. The method of Narasimhan (1983) is used to assign weights to factors that describe a single dimension - instead of comparing all the factors and criteria together, the method suggests that these are compared in isolation in accordance with the hierarchical level. There was no disagreement in the classification of the contracts for this axis.

Table 3. Assumptions for Supplier Market's Complexity Assessment.

\begin{tabular}{lll}
\multicolumn{1}{c}{ Assumptions } & \multicolumn{1}{c}{ Questionnaire } & \multicolumn{1}{c}{ lmpact on Complexity } \\
\hline Specialization of the product/service & Technology and complexity involved in the product/service & The higher, the greater the complexity \\
\hline Availability in the market & ls there a high supply in the market for the product/service? & The smaller, the higher the complexity \\
\hline Change's cost & $\begin{array}{l}\text { Which area the costs to change the item for another similar or } \\
\text { change from a current supplier to a new supplier during the } \\
\text { contract period? }\end{array}$ & The higher, the greater the complexity \\
\hline Financial dependence & $\begin{array}{l}\text { What is the degree of dependence that the supplier has on the } \\
\text { company? How much the company represents in the supplier's } \\
\text { revenue? }\end{array}$ & $\begin{array}{l}\text { The smaller, the higher the complexity } \\
\text { items already purchased by the company? }\end{array}$ \\
\hline Competition in the search & The suppliers are disputed by many buyer companies? & The smaller, the higher the complexity \\
\hline
\end{tabular}

The results found after applying the Narasimhan Method (Narasimhan, 1983) are presented in Table 4.

For the positioning in the Kraljic matrix, the scale shown in Table 5 was used, in relation to the Total Score. This scale was determined together with the focus group based on the fact that the importance score (risk) ranges from 1 to 9. Therefore, we used half the score (4.50) of importance as switching point on the quadrant. That is, for this axis, the supply risk is low.

Table 4. Results for the Horizontal Matrix Axis using the Narasimhan (1983) Method.

\begin{tabular}{cccc}
\hline Assumptions & Importance & Weight & Total Score \\
\hline Specialization of the product/service & 1 & $9 \%$ & 0.09 \\
Availability in the market & 5 & $21 \%$ & 1.05 \\
Change's cost & 7 & $32 \%$ & 2.21 \\
Financial Dependence & 1 & $6 \%$ & 0.06 \\
Potential Suppliers & 3 & $18 \%$ & 0.53 \\
Competition in the search & 3 & & 0.44 \\
& Total: & & 4.38 \\
\hline
\end{tabular}

Table 5. Scale set for the item evaluation.

\begin{tabular}{cc}
\hline Score & Definition \\
\hline 1 & Very Low Importance \\
3 & Low Importance \\
5 & Moderate Importance \\
7 & High Importance \\
9 & Very High Importance \\
\hline Source: Adapted from Olsen \& Ellram (1997)
\end{tabular}

Source: Adapted from Olsen \& Ellram (1997).

For the evaluation of the Procurement's Importance axis, two premises were defined, as shown in Table 6 .

For the evaluation of each item, the same analysis of the horizontal axis was performed using the Narasimhan method (1983). The result of the application of the method is shown in Table 7, for the Procurement's Importance axis, and the risk is considered high. For this axis there was also no disagreement in the classification of the sample contracts.

Thus being, after the reassessment of the positioning of internal movement category using the analysis of the selected sample contracts, it was found that it is in the Leverage quadrant of the Kraljic matrix, as shown in Table 8. 
Table 6. Assumptions for the Evaluation of the Procurement's Importance Axis.

\begin{tabular}{ll}
\multicolumn{1}{c}{ Assumptions } & \multicolumn{1}{c}{ Questions } \\
$\begin{array}{ll}\text { Monetary amount (actual or estimated) } & \text { How much, in cash, the item is in the total } \\
\text { involved in the item } & \text { bought by the company? }\end{array}$ The higher, the greater the risk \\
$\begin{array}{ll}\text { Added value by the item in the supply chain; } \\
\text { the impact of the item in the business quality; } \\
\text { impact of the item in the business growth }\end{array}$ & $\begin{array}{l}\text { What is the financial impact on the company, } \\
\text { caused by the lack of item or because it wasn't } \\
\text { in compliance with the ideal conditions? }\end{array}$ \\
\hline
\end{tabular}

Table 7. Results for the Vertical Matrix Axis using the Narasimhan (1983) Method.

\begin{tabular}{lccc}
\hline \multicolumn{1}{c}{ Assumptions } & Importance & Weight & Total Score \\
\hline Monetary amount (actual or estimated) involved in the item & 7 & $25 \%$ & 1.75 \\
\hline $\begin{array}{l}\text { Added value by the item in the supply chain; the impact of the item } \\
\text { in the business quality; impact of the item in the business growth }\end{array}$ & \multirow{2}{*}{ Total: } & & 6.75 \\
\hline & & & 8.50 \\
\hline
\end{tabular}

Table 8. Score for the Classification of the ltems.

\begin{tabular}{lccc}
\hline & & \multicolumn{2}{c}{ Complexity of the Supplier Market } \\
\cline { 3 - 3 } & & $<4.5$ & $>=4.5$ \\
\hline \multirow{2}{*}{ Procurement's Importance } & $<4.5$ & Noncritical & Bottleneck \\
\cline { 2 - 3 } & $>=4.5$ & Leverage & Strategic \\
\hline
\end{tabular}

\section{Application of Pagell et al. (2010) Model}

For the application of the Pagell et al. (2010) model, it is necessary to evaluate the 02 axes that compose it. The first refers to the Triple Bottom Line of Sustainability and the second refers to the Supply Risk. As in the model proposed by Pagell et al. (2010) the leverage quadrant is divided into three, a questionnaire was applied, followed by the application of the Narasimhan (1983) method for the correct positioning of the contracts chosen to be used as sample of the internal movement category.

For the evaluation axis of the Triple Bottom Line, the variables described in Table 9 were considered. Regarding the chosen scores, they were based on the Narasimhan (1983) model and accepted by the focus group that participated of the case study.

Table 9. Triple Bottom Line's Components used in the case study.

\begin{tabular}{|c|c|c|c|}
\hline & & & Reference \\
\hline \multirow{8}{*}{ Triple Bottom Line } & \multirow{3}{*}{ Environmental 1mpact } & Use of non-renewable resources & Montibeller-Filho (2001) \\
\hline & & Waste Generation & Montibeller-Filho (2001) \\
\hline & & Care Needed for the Environment & Montibeller-Filho (2001) \\
\hline & \multirow{3}{*}{ Social Impact } & Development of the Local Community & Montibeller-Filho (2001) \\
\hline & & Development of Small Suppliers & Focus Group \\
\hline & & Health and Safety of the Employees & Focus Group \\
\hline & \multirow{2}{*}{ Economic Impact } & Monetary Amount Involved & The authors \\
\hline & & Value Added by the ltem in the Business Chain & The authors \\
\hline
\end{tabular}

To choose the items that would be studied in each sphere of the Triple Bottom Line, the items found in the literature were presented and agreed with the focus group based on the reality of the company. For some dimensions, the focus group requested the inclusion of the items consistent with the reality of the company.

As seen on Table 10, for each dimension of the Triple Bottom Line, with the support of a questionnaire, Narasimhan method (1983) was applied, for the dimensions to be evaluated with the goal to study whether the category is subject to having more than one Triple Bottom Line dimension of high risk, which is one of the position variables in the model by Pagell et al. (2010).

Table 11 presents the consolidated results of the Narasimhan (1983) weighting Method for each dimension. It worth remembering that Table 5 is also being scaled by the degree of risk rather than the degree of importance. Thus, one can reach the conclusion that for the environmental (Total Score $=7.40$ ), social (Total Score $=7.36$ ), and economic (Total Score $=8.50$ ) dimensions, the risk is considered high. 
Table 10. Analysis of the dimensions: environmental, social and economic.

\begin{tabular}{|c|c|c|c|}
\hline Dimension & Assumptions & Questions & Impact \\
\hline \multirow{3}{*}{ Environmental Dimension } & Use of non-renewable resources & $\begin{array}{l}\text { What are the resources needed to } \\
\text { carry out the services? } \\
\text { These resources have any control } \\
\text { program or reduced consumption } \\
\text { program? }\end{array}$ & $\begin{array}{l}\text { If the use is high, the environmental } \\
\text { impact will also be high. }\end{array}$ \\
\hline & Waste generation & $\begin{array}{l}\text { The contracts that meet the category } \\
\text { Internal Movement generate large } \\
\text { amounts of waste? }\end{array}$ & $\begin{array}{l}\text { If the generation is high, the } \\
\text { environmental impact will also be } \\
\text { high. }\end{array}$ \\
\hline & Care needed for the environment & $\begin{array}{l}\text { What are the environmental risks } \\
\text { that may lead to problems in } \\
\text { the execution of the activities } \\
\text { contracted? }\end{array}$ & $\begin{array}{l}\text { If the care needed is high, the } \\
\text { environmental impact will also be } \\
\text { high. }\end{array}$ \\
\hline \multirow{3}{*}{ Social Dimension } & Development of the local community & $\begin{array}{l}\text { What is the impact on the } \\
\text { development of the communities } \\
\text { living around the operations (income } \\
\text { generation, health improvement, } \\
\text { education)? }\end{array}$ & $\begin{array}{l}\text { If the development impact is high, } \\
\text { the social impact is also high. }\end{array}$ \\
\hline & Development of small suppliers & $\begin{array}{l}\text { What is the degree of development } \\
\text { of the suppliers in operation sites of } \\
\text { the mining activities? }\end{array}$ & $\begin{array}{l}\text { If the need for small suppliers' } \\
\text { development is high, the social } \\
\text { impact is also high. }\end{array}$ \\
\hline & Health and safety of the employees & $\begin{array}{l}\text { What is the importance given to } \\
\text { health and safety items? }\end{array}$ & $\begin{array}{l}\text { If the degree of importance is high, } \\
\text { the social impact is also high. }\end{array}$ \\
\hline \multirow[b]{2}{*}{ Economic Dimension } & $\begin{array}{l}\text { Monetary amount (actual or } \\
\text { estimated) involved in the item }\end{array}$ & $\begin{array}{l}\text { How much, in cash, the item is in } \\
\text { the total bought by the company? }\end{array}$ & $\begin{array}{l}\text { The higher the amount, the greater } \\
\text { the Economic risk. }\end{array}$ \\
\hline & $\begin{array}{l}\text { Added value by the item in the } \\
\text { supply chain; the impact of the item } \\
\text { in the business quality; impact of the } \\
\text { item in the business growth. }\end{array}$ & $\begin{array}{l}\text { What is the financial impact caused } \\
\text { by the lack of item or because it } \\
\text { wasn't in compliance with the ideal } \\
\text { conditions? }\end{array}$ & $\begin{array}{l}\text { The higher, the greater the Economic } \\
\text { risk. }\end{array}$ \\
\hline
\end{tabular}

Table 11. Result of the Total Weighting to assess the Environmental, Social and Economic Impacts.

\begin{tabular}{|c|c|c|c|c|}
\hline Dimension & Assumptions & Importance & Weight & Total Score \\
\hline \multirow{3}{*}{ Environmental Dimension } & Use of non-renewable resources & 5 & $20 \%$ & 1.00 \\
\hline & Waste generation & 5 & $20 \%$ & 1.00 \\
\hline & Care needed for the environment & 9 & $60 \%$ & 5.40 \\
\hline \multirow{3}{*}{ Social Dimension } & Development of the local community & 5 & $26 \%$ & 1.30 \\
\hline & Development of small suppliers & 3 & $10 \%$ & 0.30 \\
\hline & Health and safety of the employees & 9 & $64 \%$ & 5.76 \\
\hline \multirow[b]{2}{*}{ Economic Dimension } & Monetary amount (actual or estimated) involved in the item & 7 & $25 \%$ & 1.75 \\
\hline & $\begin{array}{l}\text { Added value by the item in the supply chain; the impact of } \\
\text { the item in the business quality; impact of the item in the } \\
\text { business growth. }\end{array}$ & 9 & $75 \%$ & 6.75 \\
\hline
\end{tabular}

To confirm the position within the model by Pagell et al. (2010), the horizontal axis was also analyzed. For this analysis, the same method of the previous axis was used. In this axis, there was no disagreement in the allocation of the contracts studied.

For the evaluation axis of the supply risk, the investment variables of the Relationship with the supplier and the Differentiation of Services Offered were added to the Kraljic (1983) model, both set in conjunction with the focus group based on the continuity practices presented in the model by Pagell et al. (2010), as shown in Table 12. Regarding the scores chosen, they were based on the assumptions shown in evaluation of the vertical axis.

Table 12. Assumptions added to the Supply Risk Evaluation.

\begin{tabular}{ll}
\multicolumn{1}{c}{ Assumptions } & \multicolumn{1}{c}{ Questions } \\
$\begin{array}{l}\text { Investment in the Relationship with the } \\
\text { Supplier }\end{array}$ & $\begin{array}{l}\text { How much time, money and resources are } \\
\text { spent to maintain a partnership relationship } \\
\text { with the supplier? }\end{array}$ \\
\hline Differentiation of Services Offered & $\begin{array}{l}\text { ls there the need to customize or most of the } \\
\text { services are standardized? How often these } \\
\text { alternative solutions are offered? }\end{array}$ \\
\hline
\end{tabular}


Table 13 shows the result of the Narasimhan (1983) weighting Method. Thus, one can reach the conclusion that for the Supply Risk axis, the risk is high.

Table 13. Result of the Total Weighting for the Evaluation of the Supply Risk Axis.

\begin{tabular}{lccc}
\hline \multicolumn{1}{c}{ Assumptions } & Importance & Weight & Total Score \\
\hline Specialization of the product/service & 1 & $6.2 \%$ & 0.06 \\
Availability in the market & 5 & $13.2 \%$ & 0.66 \\
Change's cost & 7 & $26.8 \%$ & 1.88 \\
Financial Dependence & 1 & $4.0 \%$ & 0.04 \\
Potential Suppliers & 3 & $18.3 \%$ & 0.55 \\
Competition in the search & 3 & $10.7 \%$ & 0.32 \\
Investment in the Relationship with the Supplier & 5 & $13.1 \%$ & 0.66 \\
Differentiation of Services Offered & 3 & $7.6 \%$ & 0.23 \\
& & & 4.39 \\
\hline
\end{tabular}

\subsection{Discussions}

Analyzing the horizontal and vertical axis we would not be able to classify the internal movement category within the Pagell et al. model. (2010) if solely the scores found were analyzed. In the vertical axis, it would fit as Strategic Commodity and analyzing the horizontal axis, it would be considered as Transactional Commodity.

This fact can be explained by the specific nature of the internal movement activity in the mining industry, since it is a category that really increases the risks in all the spheres of the Triple Bottom Line, but at the same time, presents a moderate risk of low supplies.

However, analyzing the classifications proposed by the model, one of the most striking features of the Strategic Commodity is in relation to the supplying risk the buyer takes from low to high.

It appears that the internal movement category has a risk of low supply, however, to include the analysis of the social, and environmental dimensions (which have high risk within the category). lt's possible an increase in the need to invest in the relationship development with suppliers and in the need to take the degree of supply risk from low to high because there is a need to decrease the risk in the Triple Bottom Line. To achieve this finding, the relationship with the supplier must be very close, developing it and closely analyzing their financial data, its dependence on the studied company, how it is seen in society, what is its degree of sustainable development, what it does to decrease the environmental impact of the services provided, among others. This relationship is built over time and therefore there is the need for long-term contracts.

Thus, the buyer takes this risk to high, because if this supplier leaves the contracted supplier's base, all the investment in it will be lost by the mining company. With this, the most appropriate classification for the internal movement category is as Strategic Commodity. Within this classification, it is necessary to have long-term contracts to develop the relationship with the supplier and thus decrease the risk of the Triple Bottom Line's elements within this category.

As an initial suggestion, this paper exemplifies some possible actions that can be taken in conjunction with the supplier to mitigate the risk. Regarding the social elements, some actions can be carried out in conjunction, such as to develop the local community (hiring local workforce for the contract, investment in the local community's infrastructure), programs to monitor the health and the safety of the employees (workshops, supervision of the necessary safety items, periodic examinations for employees).

Regarding the environmental elements, some actions can be carried out in conjunction, such as lectures on waste of non-renewable resources, programs to prevent waste generation and even the development of new technologies to reduce this generation, training about the impacts that this activity has in the environment and how these may be reduced.

Regarding the economic element, the viability of the contracting company giving a loan for the contracted company must be analyzed, so that the contracted company can buy the necessary equipment for the service execution at lower rates than those practiced by the market. This type of analysis must carry out actions in conjunction to increase the equipment lifespan, reducing the need to reinvest during the contract term, developing together a back-up action plan if a problem occurs during the execution of the services - which paralyzes the activities contracted without any contractual fines, seeing that the profits lost by activity breakdown is higher than the value received in the fines. 


\section{Final comments}

This study aimed to identify which elements must be considered for the application of sustainability in the contracting of services. The concept of sustainable procurement may be understood as a solution to integrate environmental and social considerations in all of the steps of the procurement and contracting process, aiming to reduce impacts on human health, environment and human rights.

Within the procurement process, the Triple Bottom Line can and should be implemented in order to obtain a sustainable procurement process which will help the company to gain a competitive advantage in the market in which it operates. The balance among the three elements (social, environmental and economic) is essential for the company to achieve sustainable development. However, as shown in the applied model by Pagell et al. (2010), for each type of purchase, there are characteristics in each of these spheres that should be taken into account in the planning processes.

According to the model applied in the case study, for each existing type of purchase in the Kraljic (1983) portfolio model there is a specific treatment model by Pagell et al. (2010). Within this model, the items that should be studied for the application of the procurement's sustainability are: the threat to the Triple Bottom Line's elements; Supply Risk and Planning Horizon. However, this model does not make clear which strategy to adopt for each classification in relation to the risks found.

Within the case study conducted, it was found that the contracts of the internal movement's category of the company, are part of the leverage quadrant of the Kraljic matrix. Using this definition and applying the model by Pagell et al. (2010), the category fits as a Strategic Commodity. Items that fit in this category have a risk in the strategic supply, because they need investments made by the buyer in the relationship with the supplier. These investments are carried out due to the social and environmental elements that are at high risk. This initiative minimizes threats to the Triple Bottom Line and creates new opportunities for a lasting relationship, but increases the risk of investment loss if the supplier is replaced.

As the chosen sector was mining, a great target of pressures in relation to environmental, social, and economic sustainability due to the influence that this sector generates in the society in general, it would be interesting to carry out this study in an industry with smaller impacts on the dimensions of Triple Bottom Line for evaluation if the sustainable theme is feasible to be applied in other sectors of the economy - as this topic is very recent and few studies have been carried out on the application of it.

Finally, a model that complements the model proposed by Pagell et al. (2010) is necessary to define strategies for the features found as a risk. For example, in the presented case study it was found that all the Triple Bottom Line elements are at high risk within the internal movement's category. However, how each should be treated within the sustainable procurement issue is not defined by the existing model. It is necessary to open for all classifications found in this strategies model for possible scenarios and monitoring plans for these. The only point referring to the classification found in the case study is the need for an investment in the relationship with the supplier in order to minimize the risks, but how this investment should be carried out is not explained, as well as how it should be applied in relation to every dimension of the Triple Bottom Line.

\section{Acknowledgements}

The authors acknowledge the support of National Council for Scientific and Technological Development (CNPq) (311723/2013-6) and Foundation for Support of Research in the State of Rio de Janeiro (FAPERJ) (112.038/2013).

\section{References}

Amindoust, A., Ahmed, S., Saghafinia, A., \& Bahreininejad, A. (2012). Sustainable supplier selection: a ranking model based on fuzzy inference system. Applied Soft Computing, 12(6), 1668-1677. http://dx.doi.org/10.1016/j.asoc.2012.01.023.

Andrade, R. 0. B., Tachizawa, T., \& Carvalho, A. B. (2000). Gestão Ambiental: enfoque estratégico aplicado ao desenvolvimento sustentável. São Paulo: Makron Books.

BCSD Portugal. Conselho Empresarial para o Desenvolvimento Sustentável. (2008). Procurement sustentável: guia prático de implementação. Retrieved in 3 June 2016, from http://www.bcsdportugal.org/wp-content/uploads/2013/11/YMT-2008-Procurement-sustentavel.pdf

Bensaou, M. (1999). Portfolios of buyer-supplier relationships. Sloan Management Review, 40(4), 35-41. Retrieved in 3 June 2016, from http://sloanreview.mit.edu/article/portfolios-of-buyersupplier-relationships/

Bowen, F. E., Cousins, P. D., Lamming, R. C., \& Faruk, A. C. (2001). The role of supply management capabilities in green supply. Production and Operations Management, 15(2), 63-75. http://dx.doi.org/10.1111/j.1937-5956.2001.tb00077.x.

Carr, A. S., \& Smeltzer, L. R. (1999). The relationship of strategic purchasing to supply chain management. European of Purchasing \& Supply Management, 5(1), 43-51. http://dx.doi.org/10.1016/S0969-7012(98)00022-7. 
Carter, C. R., Ellram, L. M., \& Ready, K. J. (1998). Environmental purchasing: benchmarking our German counterparts. International Journal of Purchasing and Materials Management, 34(3), 28-38. http://dx.doi.org/10.1111/j.1745-493X.1998.tb00299.x.

Carter, J. R., \& Narasimhan, R. (1996). Is purchasing really strategic? International Journal of Purchasing and Materials Management, 32(4), 20-28. http://dx.doi.org/10.1111/j.1745-493X.1996.tb00216.x.

Croom, S. R. (2000). The impact of web-based procurement on the management of operating resources supply. The Journal of Supply Chain Management, 36(1), 4-13. http://dx.doi.org/10.1111/j.1745-493X.2000.tb00065.x.

Dubois, A., \& Pedersen, A. C. (2002). Why relationships do not fit into purchasing portfolio models: a comparison between the portfolio and industrial network approaches. European Journal of Purchasing \& Supply Management, 8(1), 35-42. http://dx.doi.org/10.1016/ S0969-7012(01)00014-4.

Ennis-Reynolds, G. (2002). Sustainable development and multiplexes. Journal of Leisure Property, 2(4), 317-331. http://dx.doi. org/10.1057/palgrave.rlp.5090153.

Gaither, N., \& Frazier, G. (2001). Administração da produção e operações. São Paulo: Pioneira Thomson Learning.

Gelderman, C. J., \& Van Weele, A. J. (2002). Strategic direction through purchasing portfolio management: a case study. The Journal of Supply Chain Management, 38(2), 30-37. http://dx.doi.org/10.1111/j.1745-493X.2002.tb00127.x.

Gelderman, C. J., \& Van Weele, A. J. (2003). Handling measurement issue and strategic directions in kraljic's purchasing portfolio model. Journal of Purchasing and Supply Management, 9(5-6), 207-216. http://dx.doi.org/10.1016/j.pursup.2003.07.001.

Hadeler, B. J., \& Evans, J. R. (1994). Supply strategy: capturing the value. Industrial Management (Des Plaines), 36(4), 3-14.

Handfield, R. B., Krause, D. R., Scannell, T. V., \& Monczka, R. M. (2000). Avoid the pitfalls in supplier development. Sloan Management Review, 41(1), 37-49.

Handfield, R. B., Sroufe, R., \& Walton, S. (2005). Integrating environmental management and supply chain strategies. Business Strategy and the Environment, 14(1), 1-19. http://dx.doi.org/10.1002/bse.422.

Handfield, R. B., Walton, S. V., Seegers, L. K., \& Melnyk, S. A. (1997). Implementing sustainable sourcing: green' value chain practices in the furniture industry. Journal of Operations Management, 15(4), 293-315. http://dx.doi.org/10.1016/S0272-6963(97)00004-1.

Hayes, R. H., \& Wheelwright, S. C. (1984). Restoring our competitive edge: competing through manufacturing. USA: John Wiley \& Sons. Retrieved in 3 June 2016, from http://id.lib.harvard.edu/aleph/001157153/catalog

Hilson, G., \& Murck, B. (2000). Sustainable development in the mining industry: clarifying the corporate perspective. Resources Policy, 26(4), 227-238. http://dx.doi.org/10.1016/S0301-4207(00)00041-6.

Karna, J., Hansen, E., \& Juslin, K. (2003). Social responsibility in environmental marketing planning. European Journal of Marketing. Bradford, 37(5-6). http://dx.doi.org/10.1108/03090560310465170.

Kraljic, P. (1983). Purchasing must become supply management. Harvard Business Review, 61(5), 109-117. Retrieved in 3 June 2016, from https://hbr.org/1983/09/purchasing-must-become-supply-management

Krause, D. R., Vachon, S., \& Klassen, R. D. (2009). Special topic forum on sustainable supply chain management: introduction and reflections on the role of purchasing management. The Journal of Supply Chain Management, 45(4), 18-25. http://dx.doi. org/10.1111/j.1745-493X.2009.03173.x.

Meehan, J., \& Bryde, D. (2011). Sustainable procurement practice. Business Strategy and the Environment, 20(2), 94-106. http://dx.doi. org/10.1002/bse.678.

Montibeller-Filho, G. (2001). 0 movimento ambientalista e o desenvolvimento sustentável - DS. In G. Montibeller-Filho. $O$ mito do desenvolvimento sustentável: meio ambiente e custos sociais no moderno sistema produtor de mercadorias. Florianópolis: UFSC.

Narasimhan, R. (1983). An analytical approach to supplier selection. Journal of Purchasing and Materials Management, 19, 27-32.

Nellore, R., \& Soderquist, K. (2000). Portfolio approaches to procurement: analyzing the missing link to specifications. Long Range Planning, 33(2), 245-267. http://dx.doi.org/10.1016/S0024-6301(00)00027-3.

Olsen, R. F., \& Ellram, L. M. (1997). A portfolio approach to supplier relationships. Industrial Marketing Management, 26(2), $101-113$. http://dx.doi.org/10.1016/S0019-8501(96)00089-2.

Pagell, M., \& Wu, Z. (2009). Building a more complete theory of sustainable Supply Chain Management using case studies of ten exemplars. The Journal of Supply Chain Management, 45(2), 37-56. http://dx.doi.org/10.1111/j.1745-493X.2009.03162.x.

Pagell, M., Wu, Z., \& Wasserman, M. E. (2010). Thinking differently about purchasing portfolios: an assessment of sustainable sourcing. The Journal of Supply Chain Management, 46(1), 57-73. http://dx.doi.org/10.1111/j.1745-493X.2009.03186.x.

Porter, M. E., \& Kramer, M. (2006). Strategy and society: the link between competitive advantage and corporate social responsibility. Harvard: Harvard Business Review. Retrieved in 3 June 2016, from https://hbr.org/2006/12/strategy-and-society-the-link-betweencompetitive-advantage-and-corporate-social-responsibility

Porter, M. E., \& Van der Linde, C. (1995). Green and competitive: ending the stalemate. Harvard Business Review, 73(5), $120-134$. Retrieved in 3 June 2016, from https://hbr.org/1995/09/green-and-competitive-ending-the-stalemate

Ruparathna, R., \& Hewage, K. (2015). Sustainable procurement in the Canadian construction industry: current practices, drivers and opportunities. Journal of Cleaner Production, 109, 305-314. http://dx.doi.org/10.1016/j.jclepro.2015.07.007.

Sancha, C., Gimenez, C., \& Sierra, V. (2016). Achieving a socially responsible supply chain through assessment and Collaboration. Journal of Cleaner Production, 112, 1934-1947. http://dx.doi.org/10.1016/j.jclepro.2015.04.137.

Schaltegger, S., Burritt, R., \& Petersen, H. (2003). An introduction to corporate environmental management: striving for sustainability. Sheffield: Greenleaf.

Sharma, S., \& Henriques, 1. (2005). Stakeholder influences on sustainability practices in the Canadian forest products industry. Strategic Management Journal, 26(2), 159-180. http://dx.doi.org/10.1002/smj.439.

Simpson, D., Power, D., \& Samson, D. (2007). Greening the automotive supply chain: a relationship perspective. International Journal of Operations \& Production Management, 27(1), 28-48. http://dx.doi.org/10.1108/01443570710714529.

Tate, W., Ellram, L., \& Kirchoff, J. (2010). Corporate social responsibility reports: a thematic analysis related to supply chain management. The Journal of Supply Chain Management, 46(1), 19-44. http://dx.doi.org/10.1111/j.1745-493X.2009.03184.x. 
Terpend, R., Krause, D. R., \& Dooley, K. J. (2011). Managing buyer-supplier relationships: empirical patterns of strategy formulation in industrial purchasing. The Journal of Supply Chain Management, 471), 73-94. http://dx.doi.org/10.1111/j.1745-493X.2010.03215.x.

Weele, A. V. (2010). Purchasing and Supply Chain Management: analysis, strategy, planning and practiced. Hampshire: Cengage Learning EMEA.

Weele, A.V. (2002). Purchasing and Supply Chain Management. London: Thomson Learning.

World Commission on Environment and Development - WCED. (1987). Our common future. Oxford: Oxford University Press.

Wu, H. J., \& Dunn, S. C. (1995). Environmentally responsible logistics systems. International Journal of Physical Distribution \& Logistics Management, 25(2), 20-38. http://dx.doi.org/10.1108/09600039510083925.

Xie, G. (2016). Cooperative strategies for sustainability in a decentralized supply chain with competing suppliers. Journal of Cleaner Production, 113, 807-821. http://dx.doi.org/10.1016/j.jclepro.2015.11.013.

Yin, R. K.(2005). Estudo de caso: planejamento e métodos (3rd ed.). Porto Alegre: Bookman.

Received: June 3, 2016

Accepted: Feb. 16, 2017 